\title{
Melestarikan Keterampilan Rias Manten Jawa Dikalangan Muda Gunungkidul
}

\author{
Muhammad Aga Sekamdo ${ }^{1)} \mid$ Eko Wiratno $^{2)}$ \\ ${ }^{1,2)}$ Sekolah Tinggi Ilmu Administrasi Madani \\ muhammadagasekamdo@stiamadani.ac.id ekowiratno@stiamadani.ac.id
}

\begin{abstract}
Abstrak: Kondisi setiap wilayah memiliki kekhasan masing-masing baik berupa karakter masyarakat, topografi, sosio ekonomi, hingga masalah dan potensi. Kabupaten Gunungkidul yang terletak di Provinsi Daerah Istimewa Yogyakarta secara umum selama bertahun-tahun dikenal sebagai wilayah yang gersang dan tidak subur, dalam beberapa tahun belakangan telah mampu menjadi kabupaten dengan beragam obyek wisata menarik yang mengangkat kondisi perekonomian masyarakat. Namun, ada beberapa kawasan disana yang tidak memiliki obyek wisata yang dapat dikembangkan dan ditawarkan pada masyarakat luas. Permasalahan kekurangan lapangan pekerjaan dan migrasi generasi muda menjadi lingkaran setan yang pada akhirnya akan memperlambat laju pembangunan di Kabupaten Gunungkidul. Dalam upaya mengatasi permasalahan di atas, beberapa pihak dilibatkan untuk mencari solusi dan bergerak menjalankan rencana yang disepakati. Pemanfaatan akses informasi akan adanya program pemerintah yang bersesuaian dengan rencana yang disepakati menjadi pilihan yang diambil. Pelaksanaan Pelatihan Keterampilan Merias Pegantin Jawa bagi generasi muda menjadi pilihan yang diambil setelah melalui berbagai pembahasan dengan berbagi pihak. Setelah melalui proses pelatihan yang cukup panjang para peserta mendapatkan hasil yang cukup baik, beberapa diantara mereka telah memulai usaha tata rias masing-masing.
\end{abstract}

Kata Kunci: generasi muda, rias pengantin jawa, wirausaha, pelatihan, budaya, lapangan kerja

\section{Pendahuluan}

Setiap wilayah tentu memiliki keistimewaan masing-masing yang terkait dengan kondisi yang melingkupi wilayah tersebut. Sebagian wilayah dikembangkan menjadi kawasan industri karena terletak didaerah penyangga seperti Kawasan Industri Jababeka Bekasi, atau karena berdekatan dengan pelabuhan seperti Kawasan Berikat Nusantara Jakarta Utara. Di Jawa Tengah kita mengenal Kawasan Industri Semarang, Kendal dan Demak. Ada pula Sleman dan Kota Jogja yang dikenal sebagai kota pelajar karena banyaknya pusat-pusat pendidikan yang berdiri disana.

Kabupaten Gunungkidul merupakan salah satu kabupaten di wilayah Provinsi Daerah Istimewa Yogyakarta, dengan luas wilayah $1.485,36 \mathrm{~km}^{2}$ atau 46,63\% dari luas wilayah Daerah Istimewa Yogyakarta, yang terkenal dengan kondisi kekeringan dan tanah yang kurang subur, meskipun ini tidak secara keseluruhan karena masih ada beberapa kawasan yang memiliki air tanah cukup banyak. Beberapa tahun terakhir ini Pemerintah Daerah Gunungkidul menjadikan wisata sebagai unggulan wilayah tersebut. Beberapa obyek wisata yang telah berhasil dipopulerkan didominasi oleh wisata pantai, serta satu wisata air tawar yang terkenal yaitu Goa Pindul. Namun, tentu tidak semua wilayah Gunungkidul merupakan daerah pantai sehingga beberapa daerah terutama daerah kering seperti Kecamatan Rongkop relatif kurang bisa diangkat ekonominya melalui program pariwisata.

Berdasarkan data yang dikeluarkan oleh BPS, tingkat pengangguran terbuka di Gunungkidul pada tahun 2019 adalah sebesar 1,92 dan meningkat menjadi 2,16 ditahun 2020. Jika data ini kita perdalam dengan data lain yang bersumber dari Bappeda DIY maka sebenarnya tingkat pengangguran terbuka di Gunungkidul rendah, karena pada tahun 2019 tingkat pengangguran terbuka di Provinsi DIY adalah sebesar 3,14 dan tahun 2020 sebesar 4,57. Akan tetapi kita tidak dapat menjadikan tingkat pengangguran terbuka sebagai sebuah parameter keberhasilan penciptaan lapangan pekerjaan 
mengingat masih ada data lain yang disebut dengan setengah menganggur. Dengan sedikit menghitung pada data yang dipublikasikan oleh Bappeda DIY di atas, kita bisa mengetahui bahwa jumlah orang yang setengah menganggur di Provinsi DIY pada tahun 2020 adalah $34,7 \%$ atau 772.384 orang. Jumlah yang jauh di atas data jumlah pengangguran terbuka. Kondisi yang sama kami asumsikan terjadi dihampir semua wilayah termasuk di Kabupaten Gunungkidul.

Bicara tentang angkatan kerja dan pengangguran maka kita akan cenderung berbicara tentang generasi muda yang merupakan bagian yang cukup besar dari angkatan kerja tersebut. Pemuda didefinisikan sebagai warga negara Indonesia yang memasuki periode penting pertumbuhan dan perkembangan yang berusia 16 (enam belas) sampai 30 (tiga puluh) tahun. Padahal hasil Survei Sosial Ekonomi Nasional 2019 menunjukkan bahwa kelompok usia termasuk kelompok usia yang paling tinggi melakukan migrasi. Hasil survei tersebut menyebutkan bahwa usia 20-29 tahun merupakan kelompok umur yang paling banyak migran risen, yaitu sebesar 34,80\%. Dan Provinsi DIY merupakan provinsi dengan tingkat migran tertinggi untuk kelompok usia 20-29 tahun, yaitu 48,1\%.

Rakaian semua kondisi di atas memberikan kita sebuah gambaran tentang permasalahan yang dihadapi Kecamatan Rongkop, Kabupaten Gunung Kidul. Sebuah daerah yang termasuk daerah sulit air, tidak termasuk dalam Kawasan Strategis Pariwisata, berada di Provinsi dengan tingkat pengangguran (setengah menganggur dan pengangguran terbuka) sebesar 39,22\% dan memiliki ancaman migrasi penduduk usia muda (produktif) yang tertinggi di Indonesia. Penciptaan lapangan pekerjaan baru merupakan salah satu hal yang menjadi tantangan di kawasan tersebut. Ketiadaan lapangan pekerjaan baru akan menyebabkan makin tinggi pengangguran dan sekaligus mendorong terjadinya migrasi, disaat yang bersamaan migrasi akan membuat proses pembangunan yang seharusnya dilakukan oleh generasi muda menjadi sulit dilakukan. Lingkaran setan ini terus berputar jika tidak dilakukan intervensi yang tepat oleh pihak manapun.

Sebuah skema ditawarkan oleh Kementerian Desa untuk mengatasi masalah kemandegan proses pembangunan dikarenakan perginya pemuda dan melemahnya berbagai organisasi di desa.

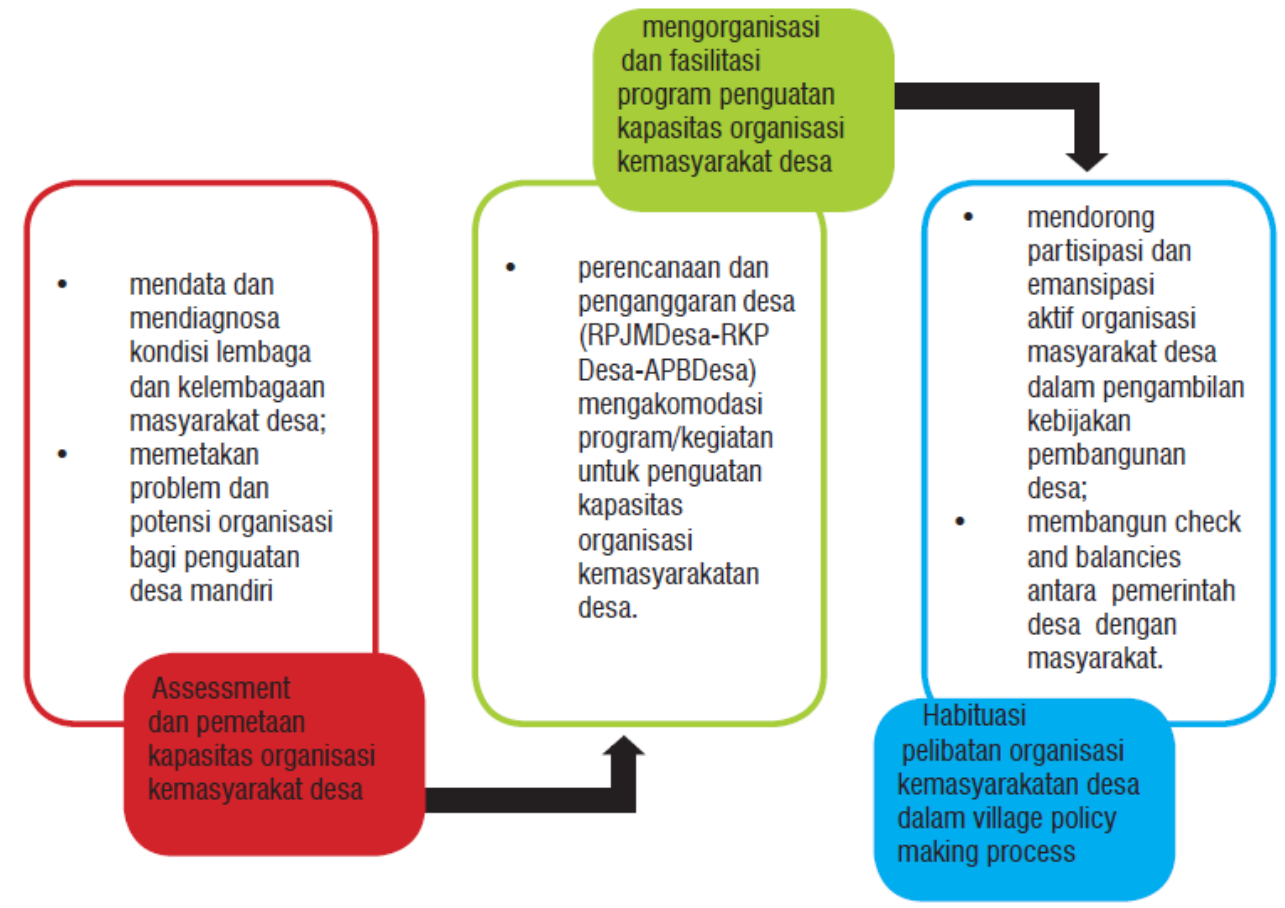

Dalam mencari solusi permasalahan ketersedian lapangan kerja di atas dengan mengacu pada skema yang ditawarkan oleh Kementerian Desa dan Sistem Inovasi Daerah (SIDa) Kabupaten Gunungkidul yang salah satunya adalah pengembangan pariwisata dengan mengangkat budaya lokal, kami berusaha mencari kegiatan usaha skala rumah tangga yang bisa dikerjakan generasi muda dan sekaligus merupakan upaya pelestarian budaya lokal. Beberapa alternatif kegiatan yang merupakan potensi dari masyarakat setempat berhasil kami petakan, juga beberapa peluang yang memungkinkan 
untuk mewujudkannya. Setelah menganalisa beberapa hal kami memutuskan titik temu ada pada pelatihan rias pengantin jawa bagi generasi muda. Pelatihan ini kami harapkan dapat menjadi sarana peningkatan kapasitas generasi muda yang menjadi bekal untuk memasuki dunia kerja maupun dunia wirausaha yang menunjang upaya pelestarian budaya lokal.

\section{Realisasi Kegiatan}

Setelah penetapan jenis kegiatan yang menurut analisa kami merupakan titik temu antara masalah, potensi, dan sekaligus mendukung rencana pembangunan pemerintah, berupa pelatihan rias pengantin jawa bagi generasi muda, kami memulai dengan menemui dan berdiskusi dengan beberapa pihak terkait. Gayung bersambut dengan seorang dukuh di Kedun Miri, Karangwuni, Rongkop, Gunungkidul yang bernama Syamsul Rodhi. Dari Dukuh Kedun Miri ini terjadilah kesepakatan kerja sama dengan sebuah LKP Melati Suci yang berlokasi di Baran, Semugih, Rongkop, Gunungkidul untuk menyelenggarakan pelatihan rias pengantin jawa bagi generasi muda secara gratis.

Paska komitmen penyelenggaraan kegiatan tersebut kami kemudian mencari peluang pembiayaan untuk pengadaan kegiatan tersebut. Akhirnya didapatkan peluang melalui program Pendidikan Keterampilan Wirausaha (PKW) yang diselenggarakan Kementerian Pendidikan dan Kebudayaan Repulik Indonesia. Langkah seperti ini perlu dikembangkan sebagai salah satu strategi cara mengatasi masalah pembangunan, yaitu membuka akses informasi program-program pemerintah kepada masyarakat. Pemberkasan untuk pemenuhan syarat administratif dilakukan cukup lama karena harus menyertakan kerja sama dengan dunia usaha serta pencarian peserta yang ternyata tidak mudah. Tidak terlalu banyak generasi muda yang memenuhi persyaratan dari kemeterian yang mau untuk mengikuti pelatihan sejenis ini. Dalam proses pencarian peserta ini kepala dukuh melakukan kerja sama dengan perangkat desa setempat yang menyebarluaskan informasi ini kepada seluruh warga setempat. Cara ini cukup berhasil, semua desa mengirimkan perwakilannya untuk mengikuti pelatihan ini. Setelah melalui proses seleksi dan verifikasi lapangan langsung dari pihak kementerian, kita diminta melakukan beberapa revisi berkas pengajuan bantuan. Akhirnya ajuan diterima dengan jumlah peserta 20 orang.

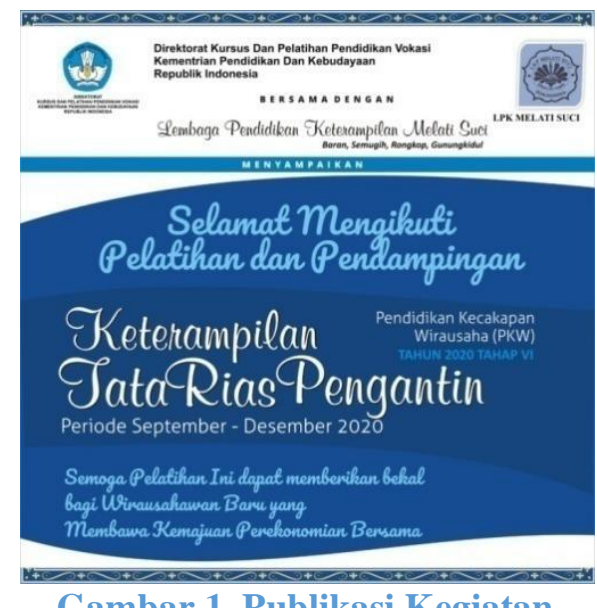

Gambar 1. Publikasi Kegiatan

Kegiatan pelatihan ini berlangsung selama tiga bulan dengan format penyampaian materi secara teori dan peragaan, lalu dilanjutkan praktik. Para peserta pelatihan mempraktikkan materi yang diajarkan secara langsung kepada sesama peserta sehingga dapat langsung dievaluasi oleh pengajar maupun oleh sesama peserta. Selain itu, para peserta mendapatkan dua peran yang akan membantu mereka dalam menjalankan usahanya nanti, yaitu peran sebagai perias dan peran sebagai yang dirias. Dalam peran sebagai perias, peserta akan dapat melihat hasil karyanya dan merasakan apasaja permasalahan yang muncul selama proses merias. Sementara dalam peran sebagai yang dirias, peserta dapat pula memahami apa yang dirasakan oleh klien nantinya, seperti panas, gatal, harus ke kamar kecil, dan sebagainya, sehingga bisa mengantisapi hal-hal tersebut dan pada akhirnya memberikan 
nilai tambah pada jasa yang ditawarkan berupa proses rias yang tidak terlalu panas, gatal, dan sebagainya. Setelah proses pelatihan yang mengasah keterampilan para peserta, maka dilanjutkan dengan pemagangan dibeberapa tempat usaha yang telah bersepakat untuk bekerja sama dengan kami sejak awal pengajuan. Selama proses pemagangan, para peserta tetap dapat pendampingan agar mereka dapat melakukan perbaikan jika terjadi kesalahan yang disampaikan oleh pihak pemilik usaha. Paska pemagangan, para peserta masih tetap mendapat pendampingan untuk upaya nya merintis usaha rias pengantin. Kegiatan ini juga dibarengi dengan pemberian paket bantuan peralatan rias secara individu bagi tiap peserta dan pakaian pengantin serta lemari yang dibagikan secara berkelompok. Selain pendampingan yang dilakukan, kami juga melibatkan pihak pemerintah daerah untuk melakukan pembinaan lebih lanjut. Dalam hal ini kami berkomunikasi dan menghadirkan Dinas Pendidikan dan Kebudayaan Kabupaten Gunungkidul, serta Camat, Kepala Desa, dan Dukuh setempat.

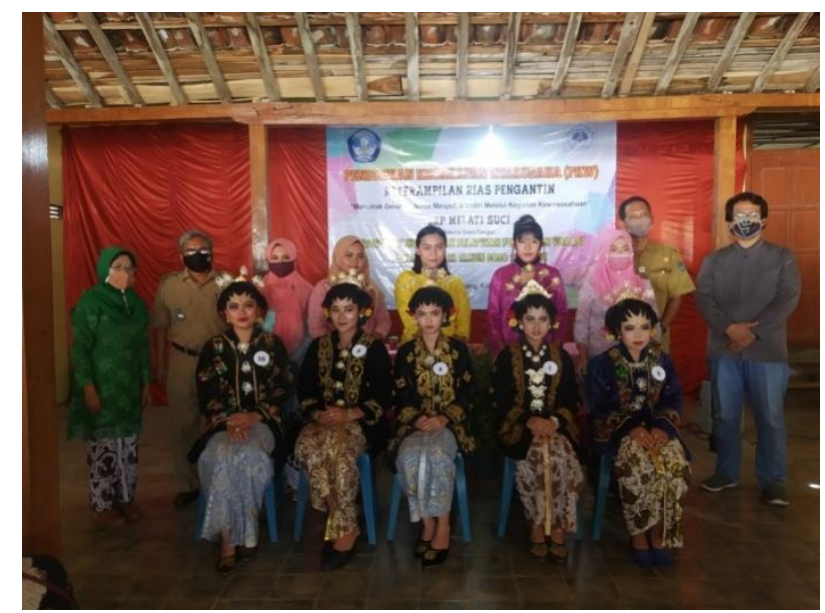

Gambar 2. Penutupan Kegiatan

Materi keterampilan merias pengantin jawa ini disampaikan oleh pihak LKP Melati Suci yang memiliki beberapa pengajar yang telah berpengalaman serta memiliki latar belakang pendidikan atau pelatihan merias secara formal. Sementara materi kewirausahaan dan pendampingan usaha dilakukan oleh kami sesuai dengan bidang ilmu kami, dengan secara berkala melakukan kunjungan dan dialog dengan para peserta. Kami juga meminta dukungan kepada pemerintah daerah setempat agar memberikan dukungan dan bantuan lebih lanjut bagi para peserta agar mereka dapat mengembangkan usahanya.

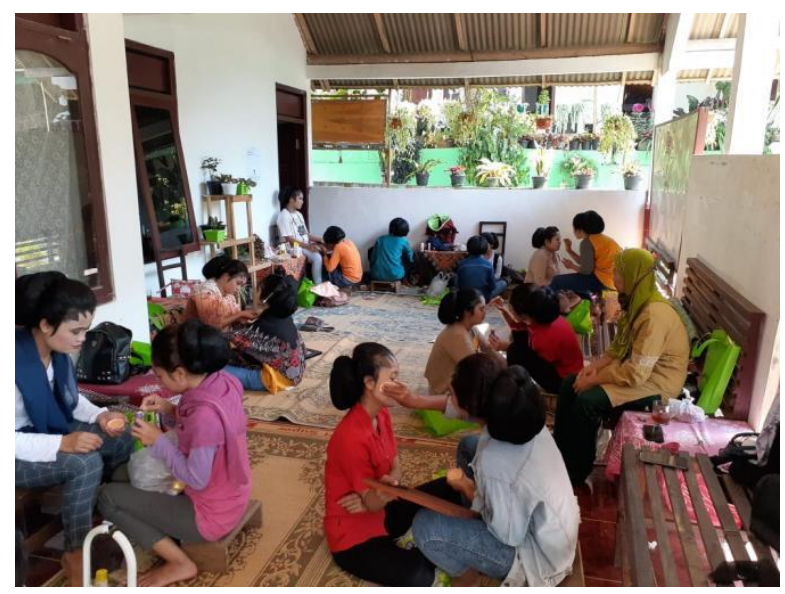

Gambar 3. Proses Praktik Peserta 


\section{Hasil}

Kegiatan ini berlangsung dengan cukup atraktif, para peserta terlihat antusias mengikuti berbagai materi baik secara teori maupun praktik. Meskipun secara umum keterampilan yang diberikan masih merupakan kemampuan dasar bagi perias, akan tetapi seiring dengan perjalanan waktu diharapkan mereka akan mampu mempelajari dan mengembangkan keterampilannya menjadi lebih baik. Tingkat kehadiran peserta mencapai $95 \%$, hanya ada beberapa kali peserta izin tidak hadir karena sakit atau kepentingan yang mendesak. Hal ini terjadi dikarenakan dari awal pelatihan para peserta sudah diberi pemahaman bahwa ketidakhadiran meskipun hanya satu kali akan berdampak pada keterampilan yang mereka miliki, bahwa semua materi saling berhubungan dan akan menjadi tidak sempurna ketika ada yang tidak diketahui serta dipahami. Pada hari terakhir pelaksanaan kegiatan, diadakan lomba merias pengantin jawa yang diikuti seluruh peserta dengan membawa model masing-masing.

Salah satu masukan dari Bapak Camat yang hadir dalam acara penutupan kegiatan adalah berharap adanya pelatihan lanjutan dengan keterampilan merias pengantin jawa pria dan semua orang yang terlibat dalam prosesi tersebut, karena pelatihan kali ini baru melatih peserta untuk merias pengantin wanita saja sementara dalam proses pernikahan jawa ada banyak pihak yang harus dirias. Dalam proses pernikahan adat jawa, selain pengantin wanita beberapa pihak yang perlu dirias juga antara lain pengantin pria, orang tua mempelai, among tamu, penerima tamu, pagar bagus, dan pagar ayu. Bahkan untuk sebagian kalangan, proses ijab qabul pun memerlukan jasa rias yang khusus, sehingga inipun perlu untuk diajarkan kepada para peserta. Masukan ini menunjukkan bahwa diperlukan kelanjutan dari pelatihan ini agar keterampilan yang diajarkan lebih lengkap, sementara untuk pelatihan kali ini waktu yang dimiliki tentu terbatas padahal bagian tersulit dan terbanyak menyita waktu dan keterampilan memang bagian merias pengantin wanita sehingga hanya cukup untuk itu saja. Itupun menurut para pengajar masih sangat kurang, karena sesungguhnya keterampilan yang diajarkan masih dasar dan baru gaya pengantin jogja saja, padahal ada beberapa gaya pengantin jawa yang berbeda-beda.

Dari sisi kewirausahaan, peserta cukup bersemangat untuk menjalankan wirausaha dibidang rias pengantin ini. Hal ini terlihat dalam pendampingan yang kami lakukan selama ini. Beberapa peserta memang masih belum percaya diri untuk langsung terjun sehingga masih menginduk ke perias yang sudah lebih dulu eksis dimasyarakat. Namun, ada beberapa peserta yang sudah memberanikan diri untuk memulai usahanya, bahkan beberapa sudah mulai mendapatkan respon positif dari masyarakat. Trik awal yang diajarkan adalah menawarkan jasa secara gratis pada keluarga atau kenalan yang akan melangsukan pernikahan untuk mendapatkan portofolio ditengah masyarakat. Dan sekarang beberapa diantara mereka telah cukup sering mendapatkan pelanggan secara profesional untuk memberikan jasa rias pengantin. Beberapa peserta yang sudah mulai berwirausaha dibidang tat arias, antara lain: Alvina Sinta Dewi (Rias Dewi), Siti Indaryanti (Ajengarta MUA), Stefani Ia Mongga (Rias Nanik), Hestiningsih (Kayla Makeup), Nur Wahyuni (Rias Zivana), Erni Yulianti (Queen Makeup), Poppy Novita (Novita Makeup), Anggi Ainisya Pra Widyasari (Ainisya Makeup), Febriantika Vida Utami (Syaqila Makeup). 


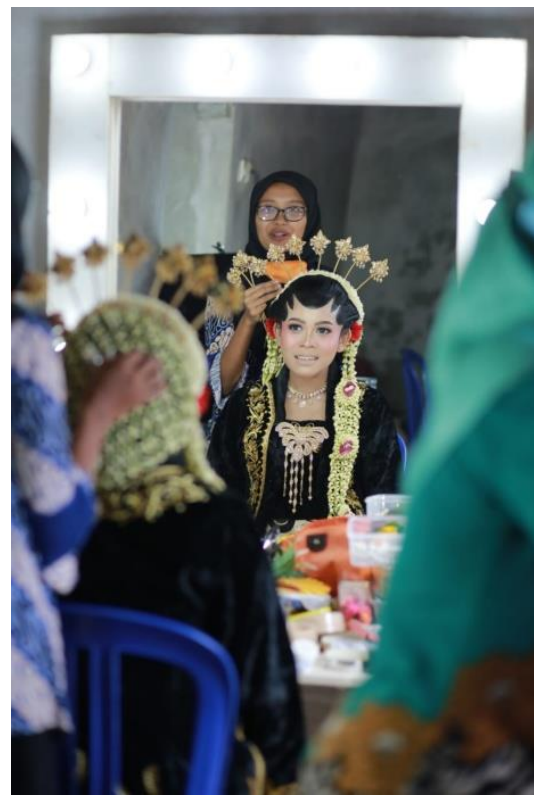

Gambar 4. Rias Dewi

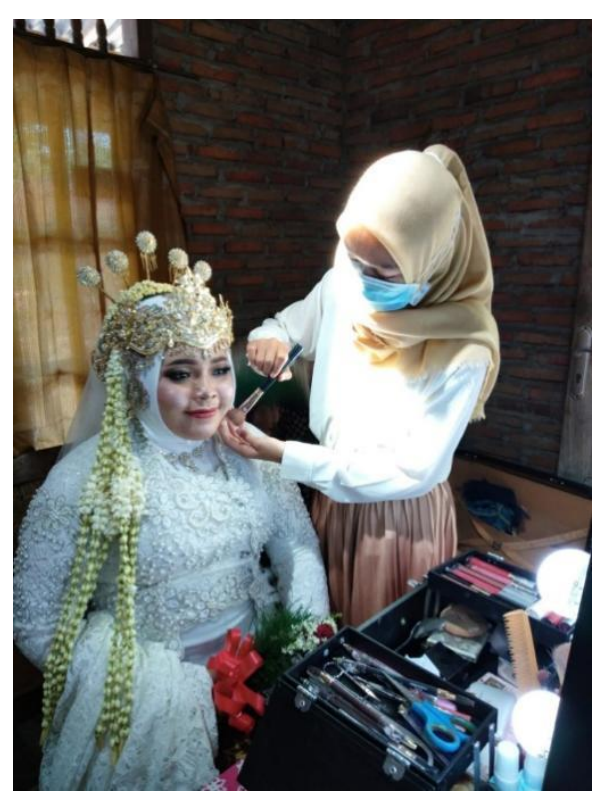

Gambar 5. Ajengarta MUA

\section{Kesimpulan}

Penciptaan lapangan kerja bagi generasi muda yang juga mendukung program pembangunan yang ditetapkan pemerintah daerah merupakan permasalahan yang berusaha dijawab oleh kegiatan pengabdian masyarakat ini. Pelibatan pihak Dukuh dan LKP setempat yang bergerak dalam bidang pelatihan rias menjadi pilihan solusi yang diambil. Pelaksanaan kegiatan pelatihan rias pengantin bagi generasi muda yang terlaksana dengan mengakses program pemerintah melalui Kementerian Pendidikan dan Kebudayaan yaitu Pendidikan Kecakapan Wirausaha (PKW) telah membuahkan hasil dengan munculnya beberapa wirausahawan muda dalam bidang tata rias, yang juga secara spesifik ikut melestarikan budaya lokal berupa riasan pengantin adat jawa gaya Yogyakarta.

\section{Daftar Pustaka}

Peraturan Daerah Kabupatan Gunungkidul Daerah Istimewa Yogyakarta Nomor 14 Tahun 2017

Tentang Perubahan atas Peraturan Daerah Kabupaten Gunungkidul Nomor 4 Tahun 2016

Tentang Rencana Pembangunan Jangka Menengah Daerah Tahun 2016-2021.

https://gunungkidulkab.bps.go.id/indicator/6/93/1/tingkat-pengangguran-terbuka-tpt-.html diakses pada: 08 Juli 2021, 11:08 am

http://bappeda.jogjaprov.go.id/dataku/data dasar/index/263-ketenagakerjaan diakses pada: $08 \mathrm{Juli}$ 2021, 11.30 am

UNDANG - UNDANG REPUBLIK INDONESIA NOMOR 40 TAHUN 2009 TENTANG KEPEMUDAAN.

Profil Migran: Hasil Survei Sosial Ekonomi Nasional 2019. BPS 2020.

Kurniawan, Borni. 2015. Desa Mandiri, Desa Membangun. Kementerian Desa, Pembangunan Daerah

Tertinggal, dan Transmigrasi Republik Indonesia.

Hasan, Muhammad, \& Muhammad Aziz. 2018. PEMBANGUNAN EKONOMI \&

PEMBERDAYAAN MASYARAKAT Strategi Pembangunan Manusia dalam Perspektif

Ekonomi Lokal. CV. Nur Lina \& Pustaka Taman Ilmu. 